\title{
Good Governance of Natural Resources for Economic Growth
}

\author{
Paiman Ahmad \\ PhD Student-National University of Public Service-Faculty of Political Sciences and Public Administration- \\ Budapest-Hungary \\ Affiliation: University of Raparin
}

\begin{abstract}
Kaufmann et al (1999) defined "governance as the traditions and institutions that determine how authority is exercised in a country." Based on available literature including thoughts of neo-institutional scholars including, Douglass North and MancurOlsan, a positive relationship between the quality of institutions, governance structures, and economic growth is found. ${ }^{2}$ In line with this concept, the proponents of the economic growth develop mentalist and policy makers like Stephen Knack considered "good governance" as the main prerequisite to sustained increases in living standards, (Knack, 2003). ${ }^{3}$ However, in the context of "good governance" the relevant variables including "politics, cultures, history, geography, and religion" might all have relevant effect on pursuing good governance in different countries. Decisively, Kaufmann $(2003, a)$ noted that "one of the most difficult issues in the field of governance is the imperfect understanding of how politics shapes governance and development outcomes. ${ }^{\prime \prime}$ Therefore; in this perspective not only the institutions, but other merits have significant contribution to reforms and good governance for the sake of fostering economic sustainability and growth. Broadly speaking, good governance contributes to economic performance, and this can be noted in the developed countries, whereas in the developing countries poor governance created poverty, and fragile economic systems. In fact, source of growth and economic well-being is not merely related to one factor, but many factors in different levels.This paper is organized in this way, the first section, reviews the state of good governance for economic growth broadly. In the second part, Governance of Natural Resources is discussed; besides the challenges of governance of natural resources is highlighted to give an overview on the concerns in regard to governing natural resource sector in the developing resource rich countries.
\end{abstract}

Keywords: Good Governance, Economic Growth, Natural Resource, Energy Sector, Developing Countries

\section{Good Governance for Economic Growth}

Before embarking on the main discussion, there is a need perhaps to start addressing the main terms, which will have important relevance to this topic. Paul (1990) remarked that economics first is "the production and distribution of the wealth." Secondly, the raw material of economics is resources, land, labor, capital. And also, the purpose of economy is to find out how to increase the human welfare. ${ }^{5}$ Apparently, economic growth is pictured with success if it is growing at $3 \%$ per annum is thought to be performing adequately, less or more is considered as failure of economics. While, according to the Growthiests, it is estimated that "growth equals increased welfare, allocate resources in such a way as to maximize growth." Analyzing the structure of management of natural resource is quite difficult; to illustrate it there is a need to start from the basics to the complex issues in the sector.Comparably, "Good Governance" is generally referred to a governance system that

\footnotetext{
${ }^{1}$ Kaufmann, Daniel, AartKraay, and Pablo Zoido-Lobatón. 1999. “Aggregating Governance Indicators.” World Bank Policy Research Working Paper 2195. Washington, DC. Available at: http://info.worldbank.org/governance/wgi/pdf/govind.pdf.

${ }^{2}$ See, among others, Knack and Keefer (1995), Mauro (1995), Clague (1997), Alesina 1998, La Porta et al. 1998, Knack 2003 and Feng 2003.

${ }^{3}$ Stepehn, Knack. (2003), cited in David, Madland.(2015). Hollowed out: why the economy does not work without a strong middle class, Oakland, California, University of California Press, p.196.

${ }^{4}$ Kaufmann, D. (2003a), .Rethinking Governance, Empirical Lessons Challenge Orthodoxy., Discussion Paper, Washington DC: World Bank Institute, available at http://www.worldbank.org/wbi/governance.

${ }^{5}$ Ed. Paul, Ekins. (1986). The living economy, a new economics in the making, London, the United Kingdom, Routledge, and Kegan Paul, p.7.

${ }^{6}$ Ibid,p.9
} 
is accountable, transparent, responsive, effective and efficient, equitable and inclusive, and follows the rule of law. ${ }^{7}$ Promoting good governance is a demand by people in many economies, reported that good governance is embedded in the key factors including, reliability, predictability and accountability, which are considered as the main key factors for ensuring national prosperity and growth. In accordance with, Owens (1987) ${ }^{8}$ and Sen (1990) have also argued for the need for economic and political freedom as necessary conditions for the economic growth and development of nations. ${ }^{9}$ Although, until now the relationship between good governance and national economic prosperity is not tackled as a necessary step for growth in many developing economics typically countries endowed with an abundant natural resources such as Iraq, Libya, Nigeria, Sudan, Congo, etc. It is highlighted that "system of governance affects the performance of the state in executing its core functions and through this, the performance of countries in meeting their major economic and social goals." ${ }^{10}$ In this regard, Ernst, G, Frankel in his book, Oil and Security, a World Beyond Petroleum noted that the power struggles have decimated the economic opportunities of its people and wasted many of the resources of the region. While petroleum has been a bonanza for the few, particularly those in power, the large masses of people in the region have benefited little." ${ }^{11}$ Apparently, the correlation between economic growth and good governance had been recorded in certain countries. Kemal (2014) stated that in the context of good governance and economic growth, successful economies require a reasonably independent central bank, and competent bank supervision that does not get dragged into short term politics. The needs for democracy, multi-party system, independent regulations, and competent public administration are determinants of economic success. ${ }^{12}$ In this regard, The United States Agency for International Development (USAID, 2002), defines good governance as a complex system of interaction among structures, traditions, functions, and processes characterized by values of accountability, transparency, and participation. In fact, energy sector governance in many developing countries is characterized by state monopoly over the resources and the ownership is entirely owned by the government.Notably, in the case of Iraq, the management of the energy sector is entrusted to various ministries and departments, mainly under the state authority, which is leading to overlapping responsibility and conflicts of interests of the stakeholders. Thus, natural resource governance in Iraq is fraught with different challenges in particular level of violence and instability, energy management is not only vital to Iraqi national economic productivity, but to global prosperity and growth too. Figure (1)

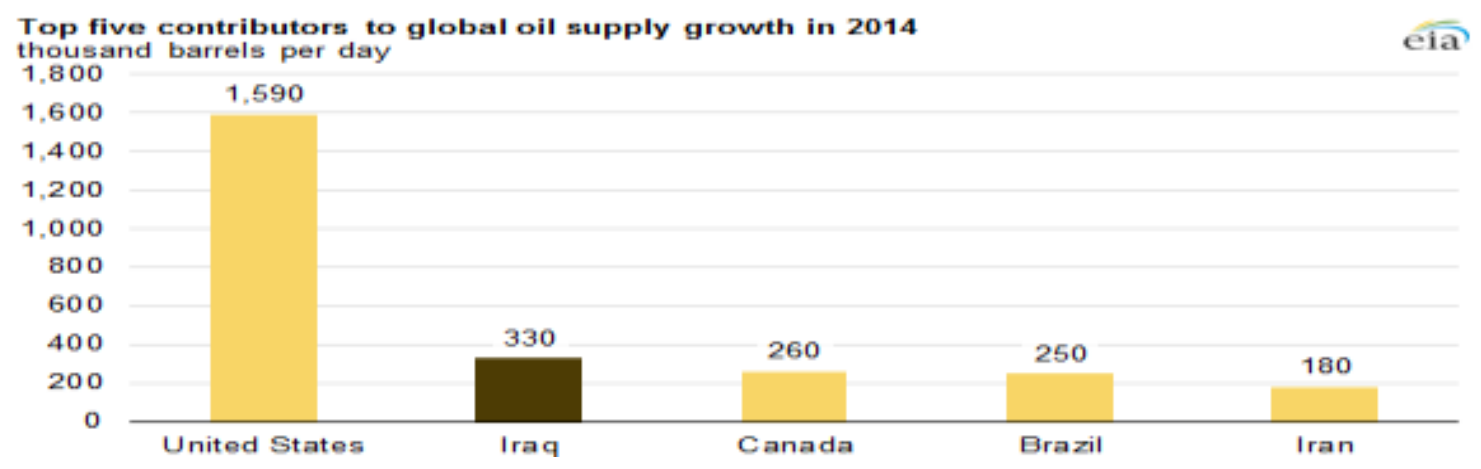

To be noted, good governance is often referred as a blocking key for economic growth with bureaucratic barriers especially in developing countries. According to a research mentioned in the Guardian, both public and private sector equally benefit from the effective and proportionate governance. The research was conducted in the UK, concluded that good governance can add significant value in the drive towards local economic growth. ${ }^{13}$

${ }^{7}$ Namsaling Community Development Center (NCDC) (ND). Good Governance and planning, accessed on October 18, 2015, available at: http://ncdcilam.org.np/ncdc-workingarea/good-governance-decentralizarion.

${ }^{8}$ Owens, E., 1987, The Future of Freedom in the Developing World, Pergamon Press.

${ }^{9}$ Paolo Mauro, “The Persistence of Corruption and Slow Economic Growth," IMF Staff Papers 51, No. 1 (2004).

${ }^{10} \mathrm{http}: / / \mathrm{www} . \mathrm{gdrc} .0 \mathrm{rg} / \mathrm{u}$-gov/doc-oecd_ggov.html

${ }^{11}$ Ernst, G, Frankel. (2007). Oil and Security, a World beyond Petroleum, Springer, p.4.

${ }^{12}$ Kemal, Dervis. (2014). Good Governance and Economic Performance, Brookings, March 13, accessed on October 7, 2015, available at: http://www.brookings.edu/research/opinions/2014/03/13-good-governance-dervis.

${ }^{13}$ Jessica, Crowe. (2014). Good governance is the key to local economic growth, the guardian, June 10, accessed on October 6, 2015, available at: http://www.theguardian.com/public-leaders-network/2014/jun/10/good-governance-localeconomic-growth. 
It is well discussed in the words of Fukuda-Parr Sakiko and Ponzio Richard (2002) "while controversies rage as to which must come first or which is more important, most would agree that all of these elements are needed, that none of these factors would be effective without improved 'governance' that shapes how these resources are used and who has a say in those decisions." ${ }^{14}$ The absence of good governance practices had resulted in poor accountability in the energy sector in many developing resource rich countries; it has threatened the financial stability of the economic system, besides it increased the risk of losing state control over energy sector, and jeopardized the energy security of the states and the world, the recent domestic violence both in Iraq and Nigeria in which both countries encounter rebel groups that weakened the role of state in providing security, domestic conflict has exacerbated the role of state in the energy sector. This has resulted in the failure of the entire monitoring, regulatory and compliance control system for the regions. Besides, the failure of the checks and balances in the energy sector, raise legitimate concerns of corrupt practices at all levels in the energy sector. Accordingly, "Countries endowed with natural resources, on average, grow more slowly than countries without such resources." ${ }^{15}$ Importantly, the notion of good governance is originally articulated by the World Bank, and IMF mainly emphasized the importance of economic and administrative reforms. ${ }^{16}$ This was prepared by institutions from advanced economies for the developing countries, which suffer from political instability, wars, corruption, poverty and crisis, but implementing the principles of good governance in developing countries is impossible. In a similar way,good governance, the U4 brief, (2008), highlighted that "measures are often aimed at improving laws and standards, but these must be enforceable and supported by efficient institutions." ${ }^{17}$ The evolution of good governance is new and is fairly linked to economic growth, since adjusting good governance elements helps in sustainable growth in the economy. It further orientates economic modernization because GNP, per capita income, literacy, livelihood, institutional capacity, and human resource development all are affected by economic growth and better governance of natural resources. In terms of transparency, the government ought to be accountable to the public and international community; Governments should immediately introduce key mechanisms for public accountability, including audits of agencies and state-owned companies and regular disclosure of information to the public." ${ }^{18}$ In recent attempts by the Extractive Industries Transparency Initiative (EITI) has developed new standards which now require public, company and projectlevel reporting in all member countries. ${ }^{19}$ In addition to that "good governance is also a key to eradicate poverty through the promotion of inclusive development. It assures that corruption is minimized, the views of minorities are taken into account and the voices of most vulnerable in the society are heard in decision making. ${ }^{20}$ Thus, the World Bank and IMF have "continued to lay a primary stress on economic and administrative reforms." ${ }^{21}$ In this respect, the central precept of good governance, that the state needs to relinquish its control of the economic sphere and, ultimately, to become more open and accountable with respect to political decision-making is

\footnotetext{
${ }^{14}$ Fukuda-Parr Sakiko and Ponzio Richard, Governance: Past, Present, Future setting the governance agenda for the Millennium Declaration, (Background paper on the HDR 2002).

${ }^{15}$ Sachs and Warner (1995), Natural resource abundance and economic growth, NBER working paper series 5398.

${ }^{16}$ Ed. Tom, Pierre Najem.,\& Martin, Hetherington.(2003). Good governance in the Middle East Oil monarchies, Routledge Curzon, London. P.7.

${ }^{17}$ Ivar, Kolstad., Tina, Soreide., \&Aled, Williams. (2008). Corruption in natural resource management - an introduction, U4 Brief ,Anti-corruption Resource Center, February 8, available online at: http://www.cmi.no/publications/file/2936corruption-in-natural-resource-management-an.pdf.

${ }^{18}$ Valerie, Marcel. (2013). Guidelines for Good Governance in Emerging Oil and Gas Producers, Chatham House, September, available online at: https://www.chathamhouse.org/sites/files/chathamhouse/public/Research/Energy,\%20Environment\%20and\%20Develop ment/0913pp_marcel.pdf.

${ }^{19}$ Publish What You Pay - United States Position Statement on Section 1504 of the Dodd-Frank Wall Street Reform and Consumer Protection Act March 14, 2014, available online at: http://www.sec.gov/comments/df-title-xv/resourceextraction-issuers/resourceextractionissuers-28.pdf.

${ }^{20}$ Namsaling Community Development Center (NCDC) (ND). Good Governance and planning accessed, October 18, 2015, available at: http://ncdcilam.org.np/ncdc-workingarea/good-governance-decentralizarion.

${ }^{21}$ Tom, Pierre, Najem.,\& Martin, Hetherington. (2003). Good governance in the Middle East Oil Monarchies, Routledge Curzon, New York, USA, Available online at: http://www.untagsmd.ac.id/files/Perpustakaan_Digital_1/GOOD\%20GOVERNANCE\%20Good\%20governance\%20in\%20the\%20Middl e\%20East\%200il\%20monarchies.pdf.
} 
obviously directly contrary to that priority. ${ }^{22}$ It is estimated that abundant reserves brings resource curse in many countries especially that phenomena is depicted in the Middle East and African countries. In this regard, "abundant natural resources in countries with poor governance fuel a wide range of ills." ${ }^{23}$ Notably, the revenues growth in energy and mineral sectors is counted negative effect in the economic system, in which while high rents in the resource sector discourage the emergence of a real economy in domestic manufacturing and industry." ${ }^{24}$ Whereas, the resource dependent countries like Botswana, Canada, Chile, and Norway, where good governance is well practiced by the governments, the economic indicators are better compare it to Iraq,Nigeria, Venezuela, Congo, etc. According to David Blackmon (2014) "oil and natural gas industry has dramatic effect on the state of Texas economy in terms of "increasing Jobs, decreasing unemployment, counted for the 24 month period from July 2009 through June of 2011, Texas created $49 \%$ of all new jobs created in the United States, those jobs were mainly resulted of the state's oil and natural gas boom." 25

\subsection{The Governance of Natural Resources and the Challenges}

Peter Eigen, the founder of Transparency International and Chair of the Extractive Industry Transparency Initiates (EITI), has addressed extractive industry as a complex sector, which is vulnerable of temptations from investors and host countries to do specific arrangements, which leads to corruption, and misuse of the revenues. Thus, he further mentioned that transparency and accountability is extremely important in this sector. ${ }^{26}$ It is been proposed by most of the world's financial governmental and non-governmental organizations that "good governance" is a vital key for growth in particular in the developing world. In many developing regions and countries, lack of rules and regulations in the management of natural resources resulted in poor economic performance. Hence, the enforcement of rules and regulations is needed for the energy sector governance. In this regard, Khan (2006) noted "the enforcement of rules is needed as the central point in the relationship between institutions and development." ${ }^{27}$ Moreover, Schneider (1999) defines good governance as the exercise of authority, or control to manage a country's affairs and resources. ${ }^{28}$ The biggest challenge for economic sustainability and growth is linked to the governance of natural resources efficiently. According to Mark Robinson, Global director of Governance in the World Resource Institute, "addressing the risks of conflict over natural resources in fragile states and enabling those states that are most vulnerable to the effects of climate change to adapt effectively to the threats of resource depletion and dislocation." ${ }^{29}$ In the international anticorruption day Ban Ki-moon said "good governance is critical for sustainable development, he added that corruption suppresses economic growth by driving up costs, breaches human rights, increases inequality, and undermines the sustainable management of natural resources. Besides, the World Bank estimated that every year between $\$ 20$ billion and $\$ 40$ billion are lost from developing countries due to corruption and bribery. ${ }^{30}$ In the International Monetary Fund (IMF) guidance for the member countries in pursuing governance, "the responsibility for good governance is addressed as the responsibility of the national authorities. The IMF

\footnotetext{
${ }^{22}$ Ibid

${ }^{23}$ http://www.cfr.org/world/beating-resource-curse-global-governance-strategies-democracy-economicdevelopment/p28005.

${ }^{24} \mathrm{http} / / / \mathrm{www} . c f r . o r g / w o r l d /$ beating-resource-curse-global-governance-strategies-democracy-economicdevelopment/p28005.

${ }^{25}$ David, Blackmon. (2014) " Oil \&amp; gas boom 2014: jobs, economic growth and security," Financial Times, February 20, accessed on December 6, 2015, available online at: http://www.forbes.com/sites/davidblackmon/2014/02/20/oil-gas-boom-2014-jobs-economic-growth-and-security/.

${ }^{26}$ Interview with Peter, Eigen (2014). Transparency, Good Governance, and Natural Resource Management, Wilson Center Staff, April 30, available online at:https://www.newsecuritybeat.org/2014/04/transparency-good-governancenatural-resource-management-interview-peter-eigen/.

${ }^{27}$ Khan M. (2006), Governance and Anti-Corruption Reforms in Developing Countries: Policies, Evidence and Ways Forward, UNCTAD, No. 42.

${ }^{28}$ H, Schneider. (1999), "Participatory Governance: The Missing Link for Poverty Reduction", Policy Brief No. 17, OECD Development Centre, Paris p. 7.

${ }^{29}$ Madaleine, Weber. (2015). Q\&A WITH Mark Robinson: the role of good governance in sustainable development, February 18, accessed on October 9, 2015, available at: http://www.wri.org/blog/2015/02/qa-mark-robinson-role-goodgovernance-sustainable-development.

${ }^{30}$ Ban, Ki-Moon, speech at the anti-corruption day, Good governance critical for development, UN stresses on AntiCorruption Day, available at: http://www.un.org/apps/news/story.asp?NewsID=46691\#.VhhCN0jFy18.
} 
emphasized the role of staff who is involved in circumstances where the authorities are not actively addressing governance issues relevance to the IMF principles; the staff should raise their concern in this regard. Adding to this, improving the management of public resources through reforms covering public sector institutions including; the treasury, central bank, public enterprises, civil service, and the official statistics function, as well as administrative procedures like expenditure control, budget management and revenue collection. Moreover, IMF concerned about institutional reforms of the treasury, budget preparation and approval procedure, tax administration and the official statistic function. ${ }^{31}$ On the September 2013, Chatham House has released a set of guidelines which are developed by a group of researchers and public officials that seek to provide policy-makers in new and emerging oil producers with targeted advice on how to embed good governance and sound management for their new petroleum sector. Indeed, the guidelines for good governance in emerging oil and gas producers identified specific challenges that face countries that are new to the petroleum industry. Moreover, the guidelines are in line with what the IMF and World Bank championed, which aimed at core objectives for supporting strategic planning in revenue generating countries. Furthermore, the guideline had enlisted set of objectives as the following:-

\section{Objective 1: Attract the most qualified investor for the long run \\ Objective 2: Maximize economic returns to the state through licensing \\ Objective 3: Earn and retain public trust and manage public expectations \\ Objective 4: Increase local content and benefits to broader economy \\ Objective 5: Ensure national oil company participation in the development of the resources \\ Objective 6: Gradually build capacity and enable actors to perform their role \\ Objective 7: Increase accountability ${ }^{32}$}

Emerging small producers named in this project are Southern Sudan, Kenya, Mozambique, Belize, Papua New Guinea. This project aims in advising the oil producers in steps for exploration, development and restructuring petroleum sector. According to the Chatham House, "it seeks to help these emerging producers to select the policy options that are most effective within a context of low institutional and capacity sector. And the two main objectives of the project, first the project is to enhance the capacity of emerging oil and gas producers to establish context-appropriate rules and institutions to govern their petroleum sectors and to engage credibly with international partners. Secondly, to ensure technical assistance is better tailored to demand. ${ }^{33}$ The emergence of good governance in the energy sectorhas recently attracted the international attention, even in the 1992 Rio Earth Summit energy was not considered as part of global governance frameworks, while the main focus was "environment and sustainable development" but in principle 23, it articulated the importance of natural resources as "The environment and natural resources of people under oppression, domination and occupation shall be protected." ${ }^{34}$ Accordingly, the Vienna Energy Forum meetings of 2009 and 2011, the following that international network built in yearly meetings of the Global Forum on Sustainable Energy. ${ }^{35}$ Additionally, the 2000 initiative of the UN Secretary- General on "Sustainable Energy for All"36 in 2011, in the SE4ALL three main objectives were given to be accomplished by 2030 including:

- To provide access to electricity and to modern cooking fuels for the billions of people currently without it.

- To double the rate of energy efficiency improvements.
${ }^{31} \mathrm{IMF}$,
(1997).
Good
Governance; the
IMF's
role,
available
at:

https://www.imf.org/external/pubs/ft/exrp/govern/govindex.htm.

${ }^{32}$ Patrick, Heller. (2013). A new guide for good governance in emerging oil producers, Natural Resource Governance Institute, September 9, accessed on October 10, 2015, available at: http://www.resourcegovernance.org/news/blog/newguide-good-governance-emerging-oil-producers.

${ }^{33}$ Chatham House, the Royal institute of international affairs, new petroleum producers discussion group, accessed on October 10, 2015, available at: https://www.chathamhouse.org/about/structure/eer-department/new-petroleumproducers-discussion-group-project.

${ }^{34}$ Rio Declaration on Environment and Development (1992), available online at: http://www.unep.org/documents.multilingual/default.asp?documentid=78\&articleid=1163.

${ }^{35} \mathrm{www}$. viennaenergyforum.org)

${ }^{36}$ (SE4ALL, www.se4all.org) in December 2011 
- To double the share of renewable energies in the overall energy end use.

Further downstream, there is a clear understanding that Rio+20 in 2012, and further initiatives for sustainable energy were international and comprehensive, a collective responsibility is shared by more than 100 countries for better future and for energy efficiency. Unfortunately, the main updates on energy efficiency and renewable energy trends are approached by energy importers and developed industrial countries, whereas the energy producing countries lag behind and could not approach such trends locally. To be mentioned, the World Energy Commission Trilemma Reports 2012-2013, ${ }^{37}$ documentedthe importance of cooperation between the public and private sector, where the government and private sector cooperate effectively for energy efficiency. Although, the United Nations had duration for the decade of Sustainable Energy for all,in (2014-2024), yet the question is, will the world be able to achieve the 7 goals of UN-Energy for All Era. The world's readiness for energy efficiency and good governance is a matter of debate since the world approaches 2016 and the 2015 Millennium Development Goals ending. This means different expectations can be mitigated in post Millennium era, what is achieved and what we can achieve is to be in the world's energy approach for development and energy sustainability in the future. Broadly speaking, energy governance is hampered by various threats, including, corruption, poor governance, instability, government monopoly, terrorist attacks, weak institutions and so on. According to, the Resource Governance Index $80 \%$ of countries fail to achieve good governance in their extractive sectors. Iraq is ranked among the weak states in this index 29 out of 58 countries, importantly, the index assesses the quality of four key governance components: the Institutional and Legal Setting; Reporting Practices; Safeguards and Quality Controls; and Enabling Environment. Furthermore, the Revenue Watch Institute calls on governments to:

- Disclose contracts signed with extractive companies.

- Ensure that regulatory agencies publish timely, comprehensive reports on their operations, including detailed revenue and project information.

- Extend transparency and accountability standards to state-owned companies and natural resource funds.

- Make a concerted effort to control corruption, improve the rule of law and guarantee respect for civil and political rights, including a free press.

- Accelerate the adoption of international reporting standards for governments and companies. ${ }^{38}$

In line with this, in the Revenue Watch Index country Ranking, Iraq is ranked as 63.8 among the second country listing of the index, which are three scales, 1. Comprehensive Revenue Transparency, 2.Partial Revenue Transparency, 3.Scant Revenue Transparency. Iraq is in the average (score 34-66), countries in the middle category of the ranking provide their citizens with information about their revenue from the extractive sector, yet have important transparency gaps in one or more specific categories of the index, "Partial Revenue Transparency".

\footnotetext{
${ }^{37}$ The World Energy Commission Trilemma Reports 2012 and 2013 (www.worldenergy.org)

${ }^{38}$ Resource Governance Index (2013). The Resource Governance Index (RGI) measures the quality of governance in the oil, gas and mining sectors of 58 countries, accessed on October 10, 2015, available at: http://www.resourcegovernance.org/rgi.
} 


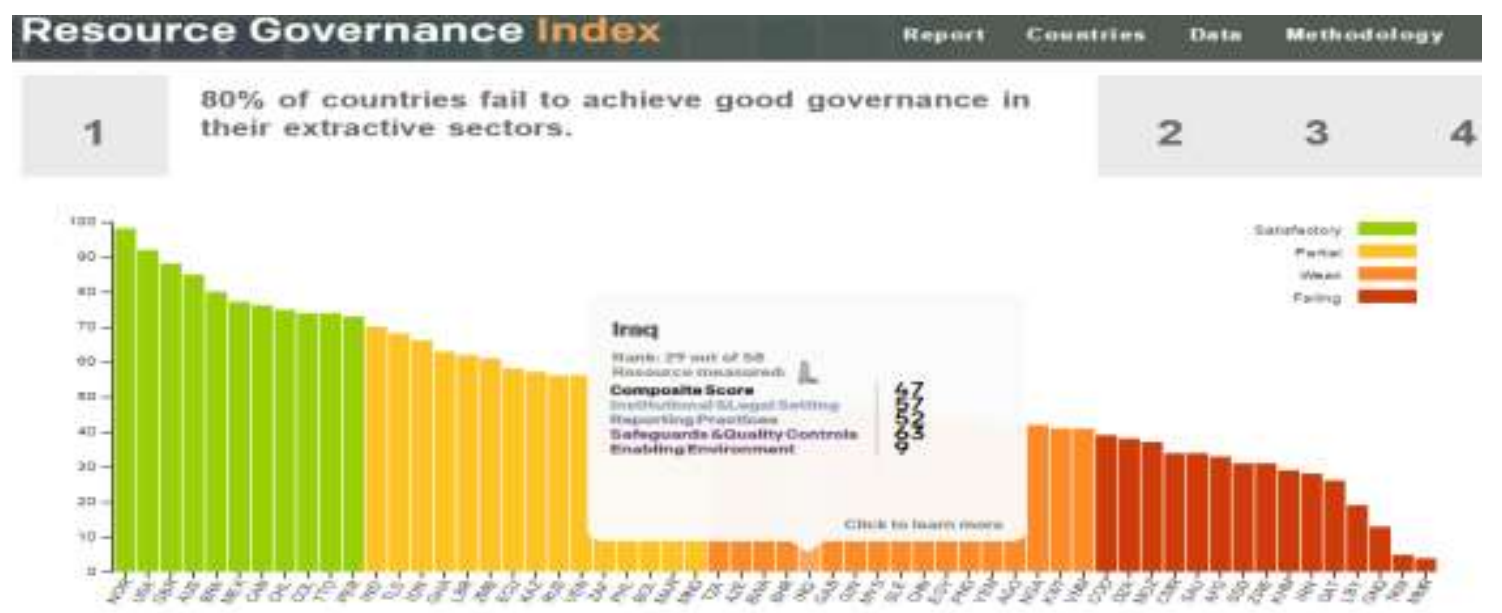

The Resource Governance Index (RGI) measures the quality of governance in the oil, gas and mining sectors of 58 countries.

Heading forward for good governance in energy sector has got international importance, and awareness, in the G20 conference, 2014, Shanghai, China, the key problems for energy governance were tackled among the G20 countries, including; understanding the key issues facing the global energy market and the role of the G20 in global energy governance. Admittedly, the conference member countries proposed to have those two important entities, the Financial Stability Board (FSB) and Energy Stability Board, ${ }^{39}$ the conference outcomes are to be considered as constructive initiatives from G20 countries on the on hand and on the other hand, it is approaching global energy governance trend. Additionally, the role of China is changed in the $21^{\text {st }}$ century and become a great energy net importer, yet China is not member of the International Energy Agency (IEA), which means China is not in most important global energy governance bodies. ${ }^{40}$

\subsection{Natural Resource Governance Challenges}

In recent year, the notion of natural resource governance "has mainly focused on better governance of natural resources, for enhancing the efficiency of resource use within the economy. At this point, two different concerns clash, the consumers concern for energy efficiency and alternatives, while for producers high price, keeping market shares, yet economic concern is not tackled seriously in developing energy abundant countries especially members of OPEC. The main challenges in energy governance domain are:

1-volatility of the natural resource sector

2- Large revenue injection in the economy is risky

3-vulnarability to "resource curse"41

Natural revenues may damage the economy, if the sector is not managed properly, distortion of revenues bring more challenges, and creates uncertainty in the economy. The challenges for developing countries are various, volatility of the revenues are affected by domestic, regional and international crisis, such as oil prices and the oil price players including Russia, Saudi Arabia and the US. Importantly, the world economy highly dependence on energy, thus the concern of sustainability is linked to revenue governance, and economic growth. Serious challenges encountered particularly in developing countries, where in some cases political horizon is short like in Nigeria and corruption is quite high, "Nigeria as a rich nation floating on oil wealth. But almost none

${ }^{39}$ Barry, Carin. (2014). Global Energy Governance and the G20, The Centre for International Governance Innovation (CIGI), June 19, 2014, accessed on October 18, 2015, available online at: https://www.cigionline.org/articles/global-energygovernance-and-g20.

${ }^{40}$ Carnegie Europe, (2014). Trade and energy governance discussion, December 2014, accessed on October 19, 2015, available online at: http://carnegieeurope.eu/2014/12/09/trade-and-energy-governance.

${ }^{41}$ Mohammed Amin Adam, Executive Director, African Centre for Energy Policy, speech on Revenue Management, online course, on 2016, Natural Resource for Sustainable Development:the fundamentals of oil, Gas, and Mining Governance. 
of it flows to the people," 42 thus rentier states inject tremendous amount of money from energy sector, in return of growth, lower productivity is experienced, because that weakens the non-resource sector like agriculture, tourism, industry. Therefore; unless the challenges and weakness of natural resource sector typically energy, if not tackled at a specific time then having large revenues will not guarantee growth and sustainability. Natural resource curse is a disease that may contaminant the whole world economic sustainability, in which many countries might not be prepared for it. Most energy countries are member in different international or regional energy organizations, yet the national structure of energy policy is quite different from the global structure, as if countries only want to be part of those clubs, Krasner (1999) in his book Sovereignty: Organized Hypocrisy, that " governments intentionally constrain their before embarking on the main discussion, there is a need perhaps to start addressing the main terms, which will have important relevance to this topic. Paul (1990) remarked that economics first is "the production and distribution of the wealth." Secondly, the raw material of economics is resources, land, labor, capital. And also, the purpose of economy is to find out how to increase the human welfare. ${ }^{43}$ Apparently, economic growth is pictured with success if it is growing at $3 \%$ per annum is thought to be performing adequately, less or more is considered as failure of economics. While, according to the Growthists, it is estimated that "growth equals increased welfare, allocate resources in such a way as to maximize growth." ${ }^{, 4}$ Analyzing the structure of management of natural resource is quite difficult; to illustrate it there is a need to start from the basics to the complex issues in the sector. Governing natural resources specifically "energy" is a top priority in one side for "consumer nations who have similar energy policy objectives, but with competing priorities, such as secure and affordable energy for economic stability, growth and development, and environmental protection." ${ }^{45}$ For achieving those objectives there is a need for international collaboration from the producing nations as well transit energy countries too. In developing countries extractive industry is fraught with "poor management, and governance which has destabilized economies, and in some cases political systems, and led to waste and inefficient use of resource itself." ${ }^{46}$ In fact, energy lies at the heart of the world's most pressing global challenges, but on global and national levels, energy is poorly governed. ${ }^{47}$

\section{Conclusion}

This paper has only touched upon the main concepts related to natural resource governance, since the critical weakness in the energy governance system is fraught with poor governance, corruption, security and lack of transparency in wealth accumulation of the sector. In this context, strengthening processes of accountability, improving the disclosure of information regarding the sector and building capacity in auditing can alleviate this risk from the energy sector.Thus, being wealthy region the concept of "good governance" will lead us to a "good state, and sustainable development in all sectors. This paper opens a path for new horizons for research and policy more accurately in the field of good governance which will support in fostering sustainability and economic growth especially in the developing countries. To conclude, good governance principles to be implemented and approached by the authorities in power in any country especially the countries that are poor in good governance of their natural resources.

\footnotetext{
${ }^{42}$ Viktor, E. Dike. (2014). Leadership and the Nigerian Economy, SAGE, March 2, available online at: http://sgo.sagepub.com/content/4/1/2158244014523792.

${ }^{43}$ Ed. Paul, Ekins. (1986). The living economy, a new economics in the making, Routledge, and Kegan Paul, London, p.7.

${ }^{44}$ Ibid,p.9

${ }^{45}$ Chatham House, (2012). The reform of global energy governance, discussion paper No 3, December, Imperial College London, available online at: https://www.chathamhouse.org/sites/files/chathamhouse/public/Research/Energy,\%20Environment\%20and\%20Developme nt/1212granthamreport energygovernance.pdf.

${ }^{46}$ Energy in Developing countries, Oxford Energy, available online at: http://www.energy.ox.ac.uk/energy-in-developing-

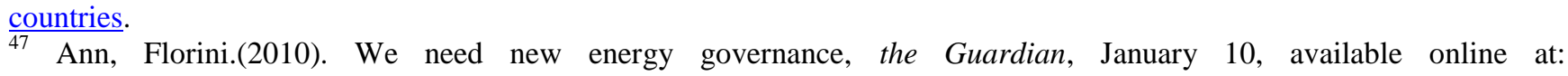
http://www.theguardian.com/commentisfree/cif-green/2010/jan/12/energy-governance-climate.
} 